\title{
THE INFLUENCE OF POISON PILLS ON EXECUTIVE COMPENSATION
}

Yuri Gomes Paiva Azevedo'

Sílvio Hiroshi Nakao²

Abstract: We examine whether the poison pills influence on the executive compensation of Brazilian publicly-traded firms, considering that there is a particularity of this anti-takeover device in Brazilian firms when compared to US firms, since the managers can include in the company's bylaws an "eternity" clause that prevents poison pills change or removal, which may lead to a managerial entrenchment, maintaining managers privileges in the detriment of minority shareholders, including increases in the executive compensation levels. To test our hypotheses, we use a sample of 217 Brazilian publiclytraded firms listed on B3 with available data on Bloomberg ${ }^{\circledR}$ database and Brazilian Securities Exchange Commission website between 2010 and 2017. We use the total, fixed and variable compensations as proxies for executive compensation. However, to mitigate several outliers of these variables, we use the quantile regression as a robust alternative to the extreme sensitivity of the ordinary least squares estimator to modest amounts of outliers. Our main results show that poison pills have a positive influence on total, fixed and variable executive compensation. Furthermore, in an exploratory way, our results show that these "eternity" poison pills also have a positive influence on these proxies of executive compensation. These findings are consistent with the entrenchment hypothesis that since managers are protected in their positions, they may obtain private benefits at the expense of shareholders, such as higher levels of executive compensation. In this sense, our study contributes to the literature by showing that although reducing the risk of a hostile takeover, the poison pills are incurring in an additional agency cost for shareholders that not always leads to the reduction of conflicts between managers and shareholders since these anti-takeover defenses seem not being adopted in the Brazilian context to benefit the shareholders, but to protect managers in their positions.

Keywords: Anti-takeover Defenses, Poison Pills, Executive Compensation.

yuri_azevedo@live.com - Universidade de São Paulo - São Paulo-SP, Brasil. http://orcid.org/0000-0002-0830-0214

${ }^{2}$ shnakao@usp.br - Universidade de São Paulo - São Paulo-SP, Brasil. http://orcid.org/0000-0003-3976-8407

- DOI: http://dx.doi.org/10.14392/asaa.2019120303

- Artigo submetido em: 06/08/2019. Revisões requeridas em: 18/11/2019. Aceito em:30/11/2019. 


\section{A INFLUÊNCIA DAS POISON PILLS NA REMUNERAÇÃO DE EXECUTIVOS}

Resumo: Nós examinamos se as poison pills exercem influência na remuneração de executivos de companhias abertas brasileiras, considerando que existe uma particularidade na adoção desse dispositivo anti-takeover em companhias brasileiras, quando comparadas às companhias americanas, uma vez que os gestores podem incluir no estatuto social uma "cláusula pétrea" que impede a alteração ou remoção das poison pills, o que pode levar ao entrincheiramento gerencial, mantendo privilégios de gestores em detrimento dos interesses de acionistas minoritários, incluindo aumentos nos níveis de remuneração dos executivos. Para testar nossas hipóteses, usamos uma amostra de 217 companhias abertas brasileiras listadas na B3, com dados disponíveis na base de dados Bloomberg ${ }^{\circledR}$ e no site da Comissão de Valores Mobiliários entre 2010 e 2017. Nós utilizamos a remuneração total, fixa e variável como proxies para a remuneração de executivos. No entanto, para mitigar diversos outliers dessas variáveis, utilizamos a regressão quantílica como uma alternativa robusta à extrema sensibilidade do estimador de mínimos quadrados ordinários a modestas quantidades de outliers. Nossos principais resultados evidenciam que as poison pills influenciam positivamente a remuneração total, fixa e variável dos executivos. Além disso, de forma exploratória, nossos resultados mostram que poison pills, quando associadas às cláusulas "pétreas", também têm uma influência positiva sobre as proxies de remuneração de executivos. Esses resultados são consistentes com a hipótese de entrincheiramento de que, quando protegidos em suas posições, os gestores podem obter benefícios privados à custa dos acionistas, como níveis mais altos de remuneração. Nesse sentido, nosso estudo contribui para a literatura ao evidenciar que embora reduzam o risco de takeover hostil, as poison pills estão incorrendo em um custo adicional de agência para os acionistas que nem sempre leva à redução de conflitos entre gestores e acionistas, ao passo que esses dispositivos anti-takeover parecem não estar sendo adotados no contexto brasileiro para beneficiar os acionistas, mas para proteger os gestores em suas posições.

Palavras-chave: Defesas Anti-takeover, Poison Pills, Remuneração de Executivos. 


\section{INTRODUCTION}

T he literature on executive compensation explores two distinct effects of anti-takeover defenses on executive compensation. On the one hand, the efficient compensation contracting hypothesis suggests that anti-takeover defenses are part of optimal contracting between managers and shareholders, in which managers of firms that adopt these anti-takeover mechanisms will receive lower levels of executive compensation than managers of firms that do not adopt them (Knoeber, 1986).

On the other hand, the managerial entrenchment hypothesis predicts that entrenched managers may use the protection provided by this mechanism to obtain contracts that further increase the level of their compensation (Borockovich, Brunarski, \& Parrino, 1997).

Based on these two competing hypothesis, empirical evidences show that there is a positive and significant influence of anti-takeover defenses on executive compensation (Borokhovich et al., 1997; Chakraborty \& Sheikh, 2010; Fahlenbrach, 2009; Jiraporn, Kim, \& III, 2005; Souther, 2016), supporting the entrenchment hypothesis and being inconsistent with the efficient contracting hypothesis.

The poison pill is one of the anti-takeover defenses examined by these prior studies, becoming a popular mechanism against hostile takeover attempts since it introduced, in 1982, in the US capital market (Ryngaert, 1988). However, although the origin and application of poison pills in the US context aim to preserve shareholders' rights and interests, in the Brazilian context, instead of benefits shareholders, poison pills may be used to perpetuate managers in their positions (Maestri, 2011).

This occurs due to particularities in the poison pills adoption by Brazilian firms, such as low triggering limits and excessively premiums. However, the most aggravating factor is that Brazilian firms may include in their bylaws "eternity" poison pills that cannot be changed or removed, that is, they are "eternity" clauses (Ambrozini, Pimenta, \& Gaio, 2015), unlike poison pills adopted by US firms, which are usually valid for a period of 10 years (Schepker, Oh, \& Patel, 2016).

These "eternity" clauses predict that the shareholders who attempt to change or remove this anti-takeover defense have to offer to purchase all of the shareholders ordinary shares (voting shares) in a tender offer by paying a premium on these shares price. Thus, the inclusion of these "eternity" clauses signals a managerial entrenchment since it makes it practically impossible that shareholders change or remove the poison pills clauses.

In addition to these particularities of poison pills in the Brazilian context, which may lead to the managerial entrenchment, we consider that there is a gap in the international literature concerning the poison pills influence on executive compensation since prior studies used a golden parachute dummy (Borokhovich et al., 1997) or the governance index proposed by Gompers, Ishii and Metrick (2003) as proxies for anti-takeover defenses (Chakraborty \& Sheikh, 2010; Fahlenbrach, 2009; Jiraporn et al., 2005; Souther, 2016).

This avenue allows us to examine the individual effect of the poison pill adoption on executive compensation, isolating this effect and reducing the noise of the relationship examined by prior studies (Chakraborty \& Sheikh, 2010; Fahlenbrach, 2009; Jiraporn et al., 2005; Souther, 2016), which are based on an index composed by 24 diverse anti-takeover defenses, with different purposes that not always focus on benefit shareholders, such as the golden parachutes, which main focus is to provide benefits to managers. In this vein, due to this gap in the literature and the particularities of poison pills in the Brazilian context, this paper investigates whether the poison pills influence on the executive compensation of Brazilian publicly-traded firms. 
We consider that the scrutiny of this relationship is relevant since the poison pill - as a corporate governance mechanism - aims to provide a higher level of protection against hostile takeovers, but not to provide private benefits to managers, such as increases in their compensation levels, which incur in an additional agency cost for shareholders. Thus, we consider relevant investigate whether poison pill adoption influences executive compensation to examine if there is an externality of this mechanism that may not be expected by shareholders.

To test this influence, we first examine the association between poison pills and three proxies of executive compensation (total, fixed and variable compensation). In our preliminary test, we examine the effect of poison pills in a broader way, without considering only the specific "eternity" clauses in order to obtain evidence that may be convergent with future findings after the sample expansion to a cross-country study, including publicly-traded firms from Canada, South Korea, France, Italy, Russia, Japan, and other countries.

However, in a second moment, considering that Brazilian firms can adopt a more restrictive group of poison pills that cannot be removed, we also examine the association between "eternity" poison pills and executive compensation proxies.

Briefly, our results reveal that firms that adopt poison pills pay higher levels of executive compensation since the poison pills are positively associated with total, fixed and variable executive compensation. Furthermore, we obtain similar results when we examine the association between "eternity" poison pills and the executive compensation proxies, corroborating the perspective that the executive compensation increases at firms where managers became entrenched (Bereskin \& Cicero, 2013).

In this vein, our paper contributes to the literature by showing that although reducing the risk of a hostile takeover, poison pills are incurring an additional agency cost for shareholders. However, we emphasize that these additional agency costs not always leading to the reduction of conflicts between managers and shareholders since poison pills and the "eternity" poison pills lead to a managerial entrenchment. Thus, protected in their positions, managers may obtain private benefits at the expense of shareholders, such as higher levels of executive compensation.

This entrenchment and, consequently, potential obtaining of private benefits may explain prior evidence that shareholders react negatively to poison pills adoption and that poison pills reduce stockholder wealth (Arikawa \& Mitsusada, 2011; Malatesta \& Walkling, 1988; Ryngaert, 1988; Sikes, Tian, Wilson, 2014). However, we highlight that the markets' reaction to poison pill adoption is not explored in our study, being a fruitful avenue that can be explored in the Brazilian context.

Considering that the literature on the effect of anti-takeover defenses on executive compensation is sparse (Chakraborty \& Sheikh, 2010), our study also contributes to this literature, since, to the best of our knowledge, is the first to examine the association between poison pills and executive compensation, bringing new evidences of the managerial entrenchment in the Brazilian context.

Finally, besides the contributions presented, our evidences may be useful for investors and regulators, as the Brazilian Securities Exchange Commission, by showing empirically the effects of poison pills and of "eternity" poison pills, suggesting that they may not be adopted in the Brazilian context to benefit the shareholders, but to propitiate benefits for managers.

\section{HYPOTHESIS DEVELOPMENT}

According to DeAngelo and Rice (1983), the anti-takeover defenses can be viewed as a type of long-term contract for incumbent managers, increasing their incentives to invest in longer-term projects, 
which lead to maximizing shareholder wealth. Based on this perspective, Knoeber (1986) extends the long-term contract described by DeAngelo and Rice (1983) to include compensation contracts.

Under the efficient compensation contracting hypothesis, Knoeber (1986) argues that anti-takeover defenses are part of optimal contracting between managers and shareholders, suggesting that managers of firms that adopt anti-takeover defenses will receive lower levels of current compensation than managers of firms that do not adopt them.

Insulated from the discipline of the market for corporate control due to the anti-takeover adoption, managers are less pressured to deliver short-term results. Thereby, they can invest in attractive projects with long-term returns that will increase shareholder value and executive compensation in future periods, in detriment of increases in current executive compensation.

An alternative perspective to the efficient compensation contracting view is the managerial entrenchment view, which predicts that anti-takeover defenses entrench incumbent managers, which, in turn, encourage them to behave opportunistically, impairing shareholder wealth (Ge \& Kim, 2014).

The managerial entrenchment takes as given the separation of ownership by shareholders from control by management (DeAngelo \& Rice, 1983). This separation was first described by Berle and Means (1932) and it is based on a contractual agency relationship that considers individuals to be rational and maximizing their own utility (Ross, 1973; Jensen \& Meckling, 1976).

Under the entrenchment hypothesis, managers may benefit from anti-takeover defenses since they help protect above-market levels of compensation. Furthermore, once an anti-takeover defense has adopted, entrenched managers may use the protection provided by this mechanism to obtain contracts that further increase the level of their compensation (Borockovich et al., 1997).

Based on these two competing views, in which the first predicts that the adoption of anti-takeover defenses tends to reduce executive compensation due to the efficient compensation contracting, while the second predicts that the adoption of these defenses exacerbates the executive compensation due to the managerial entrenchment effect, prior studies that investigated the influence of anti-takeover defenses on executive compensation support the entrenchment hypothesis and are inconsistent with the efficient contracting hypothesis.

Borokhovich et al. (1997) study is one of the first that tested empirically this relationship, based on a sample of 258 U.S. firms in the 1979-87 period, using golden parachutes as a proxy for anti-takeover defenses. Their findings are consistent with the argument that anti-takeover defenses facilitate entrenchment, since the Chief Executive Officers (CEO) of anti-takeover defenses firms received, on average, significantly higher levels of compensation than CEOs of firms that do not adopt anti-takeover defenses.

Aditionally, Borokhovich et al. (1997) suggested that CEOs of anti-takeover defenses firms used the protection that anti-takeover defenses provide them to increased their compensation levels since the dummy anti-takeover defenses influenced positively and significantly the natural log of salary and bonus in the compensation regressions.

Similarly, Jiraporn et al. (2005) investigated whether anti-takeover defenses influence CEO compensation for a sample of 4,153 U.S. firms in the 1993-2000 period. But instead of using golden parachutes as a proxy for anti-takeover defenses, as done by Borokhovich et al. (1997), they used the governance index proposed by Gompers et al. (2003), who includes poison pills, golden parachutes, staggered boards and others shareholders rights as a proxy for firm-level anti-takeover defenses.

Jiraporn et al. (2005) showed that there is a positive and significant association between governance index and CEO compensation, indicating that CEO's obtain more profitable compensation in firms with 
more levels of anti-takeover defenses. Thus, insulated from the market discipline, the CEO's of firms enjoyed higher levels of compensation due to the managerial entrenchment.

Fahlenbrach (2009) and further studies also used the governance index proposed by Gompers et al. (2003) to examine the interactions of a broad set of anti-takeover defenses and total compensation of CEOs based on a sample of U.S. firms over the period 1993-2004.

Fahlenbrach (2009) verified that there is a positive and significant influence of governance index in the total compensation, even when tested two other proxies for executive compensation, which is consistent with the entrenchment hypothesis. However, after split the firms into weaker and stronger governance groups, it was verified that the sensitivity between the governance index and executive compensation is lower in firms with weaker governance, which may be inconsistent with the entrenchment hypothesis.

Chakraborty and Sheikh (2010) also investigate if the entrenchment provided by anti-takeover defenses affected managerial compensation, based on a sample of 17,035 firm-years observations for the period 1992-2007. Their results showed that managers protected from the external control market become entrenched and that this entrenchment influenced their compensation, since the governance index had a positive and significant influence in the CEO's total compensation and CEO's cash compensation, suggesting that CEO's compensations reflected significant agency costs for firms with higher managerial entrenchment from anti-takeover defenses.

Differently from previous studies who investigated all publicly traded companies (Borokhovich et al, 1997; Fahlenbrach, 2009; Jiraporn et al., 2005) or non-financial public companies (Chakraborty \& Sheikh, 2010), Souther (2016) used a sample of 621 closed-end funds to examine, in the period between 1997 to 2011 , how takeover defenses impacted shareholder value and promoted managerial entrenchment, since these funds use the same defenses as general corporations.

Souther (2016) showed a positive and significant relation between the anti-takeover defense index and total board compensation in each of the four specifications, indicating that directors and managers used anti-takeover defenses to entrenched themselves and increased their compensation levels at the expense of shareholders.

After analyzing the previous studies, we identify that these use golden parachutes (Borokhovich et al., 1997) or the governance index proposed by Gompers et al. (2003) as proxies for anti-takeover defenses (Chakraborty \& Sheikh, 2010; Fahlenbrach, 2009; Jiraporn et al., 2005; Souther, 2016). Thus, we consider a good opportunity to extend the literature by investigating if poison pills also influence executive compensation.

Poison pills are often considered the most well-known (Huang, Wang, \& Zhou, 2013) and effective defenses to prevent hostile takeovers (Nguyen, 2017; Schepker \& Oh, 2013). However, with this high effectiveness to deter takeovers that may lead to loss of management's compensation, the poison pill adoption may entrench inefficient managers by exacerbating the free-rider problems (Ryngaert, 1988).

According to the managerial entrenchment hypothesis, poison pills insulate managers from the disciplining effects of the market for corporate control (Danielson \& Karpoff, 2006). In this sense, they give managers greater job security, provide an opportunity for them to pursue objectives related to their personal well-being and reduce the market-based discipline of a potential takeover (Mallette \& Fowler, 1992).

Thus, we predict that protected from the market for corporate control through the poison pill adoption, the managers can benefit at the expense of shareholders by increasing their compensation levels, keeping them above the market level, which is characterized as an agency conflict. Based on the above discussion, our first hypothesis is stated as follows: 
H1: Poison pills are positively associated with executive compensation.

Additionally, there is a particularity of poison pills adoption in Brazilian firms when compared to US firms, since managers can include in the company's bylaws a clause that prevents poison pills change or removal, which is known as "eternity" clause (Ambrozini et al., 2015).

The simple inclusion of this clause signals the managerial entrenchment, since it makes it practically impossible to remove the poison pill clause because it requires that the shareholder who vote to change or remove the poison pill offer to purchase all of the shareholders ordinary shares (voting shares) in a tender offer by paying a premium on the share price.

In this sense, poison pills in Brazil can perpetuate the same control group, which is never modified, maintaining managers' privileges to the detriment of minority shareholders, including increases in the executive compensation levels (Martins, 2015).

Considering that executive compensation increases at firms where managers became entrenched (Bereskin \& Cicero, 2013), and that the adoption of poison pills by Brazilian firms has particularities in relation to those adopted by US firms, due the possibility of include this anti-takeover defense in the bylaw an "eternity" clause, our second hypothesis is as follows:

H2: "Eternity" clause poison pills are positively associated with executive compensation.

\section{SAMPLE SELECTION AND RESEARCH DESIGN}

\subsection{Sample selection}

To test our hypotheses, we use a sample of Brazilian publicly traded companies listed on B3 with available data between 2010 and 2017. We consider this period due the mandatory adoption of the International Financial Reporting Standard in Brazil began in 2010, which led to an increase in the accounting information quality (Pelucio-Grecco, Geron \& Grecco, 2014).

We require financial data from Bloomberg ${ }^{\oplus}$ database as well as executive compensation and poison pills data from the Brazilian Securities Exchange Commission website. Thus, we obtain the executive compensation data from the Total Remuneration of the Board of Directors section of Reference Form, and the poison pills data from the Shares Control Alienation section from the bylaws.

Our initial sample consists of all of the firms listed on B3, but we exclude financial firms because of their specific financial and operating structures. In addition, we exclude firms that are missing necessary data. After these exclusions, the final sample consists of 1,377 observations of 217 firms, as shown in Table 1 of the sample selection procedure.

Table 1 - Sample selection procedure

\begin{tabular}{|c|c|}
\hline & Firms \\
\hline Total of Brazilian publicly traded companies & 412 \\
\hline Less: Financial companies & $(78)$ \\
\hline Less: Missing data from executive compensation & $(83)$ \\
\hline Less: Missing data from market value & $(34)$ \\
\hline
\end{tabular}


We highlight that we do not require company data in all years (2010-2017) in order to avoid survival bias. Thus, our analyses are based on unbalanced data.

\subsection{Research design}

Our first hypothesis concerns the influence of poison pills on executive compensation. Therefore, the general form of the equation that we use to test this hypothesis is as follows:

ExecutiveCompensation $=\beta 0+\beta 1$ PoisonPill $+\sum_{j=3}^{8} \beta j$ Controls $+\varepsilon$ (1)

Following prior studies (Borokhovich et al., 1997; Chakraborty and Sheikh, 2010; Cheng and Indjejikian, 2009; Fahlenbrach, 2009; Jiraporn, et al., 2005), we use several different proxies for ExecutiveCompensation.

Our first measure for executive compensation is TotalCompensation, measured by the sum of the logarithms of fixed compensation, variable compensation and stock options exercised. Our second and third measures refine the first one, separating fixed compensation and variable compensation, and excluding the stock options exercised.

Thus, our second measure is FixedCompensation, composed by the sum of the logarithms of salary, benefits, participation and other fixed compensations. Finally, our third measure is VariableCompensation, measured by the sum of the logarithms of bonus, results participation, meetings participation, commissions participation and other variable compensations.

To mitigate several outliers of dependent variables (TotalCompensation, FixedCompensation and VariableCompensation), we use the quantile regression as a robust alternative to the extreme sensitivity of the ordinary least squares estimator to modest amounts of outliers (Koenker \& Basset, 1978). In this sense, we highlight that winsorization at $1 \%$ and $99 \%$ levels did not mitigate the data outliers problem.

In addition to the advantage of non-sensitivity of quantiles to outliers and non-normally distributed errors, the quantile regression may reveal a more complete picture of the differences in the relationship at different quantiles of the conditional dependent variable, since the method can be used to predict any quantile that researcher is interested in (Conyon \& He, 2017; Nguyen, Rahman, \& Zhao, 2018). Thus, consistent with Nguyen et al., (2018), we estimate the models at the 10th, 25th, 50th, 75th and 90th quantiles.

We employ the quantile regression using PoisonPill as the interest variable in the model (1), which is a dummy variable indicating whether a firm has a poison pill defense. Additionally, considering that the poison pills in Brazil can be included in the bylaws as an "eternity" clause, which cannot be removed, we test our second hypothesis using the EternityClause as the interest variable, as follows:

ExecutiveCompensation $=\beta 0+\beta 1$ EternityClause $+\sum_{j=3}^{8} \beta j$ Controls $+\varepsilon$ (2)

The EternityClause is a dummy variable indicating whether a firm has an "eternity" clause poison pill. In either case (equations 1 and 2), we used the same executive compensation and control variables. Our control variables derive from prior studies which demonstrates that these variables may affect executive compensation. Variable definitions are shown in Appendix 1.

In line with Bhaumik and Selarka (2012) and Shehzad, Haan and Scholtens (2010), we use a dummy variable (MajorityOwnership) to control for ownership concentration. Considering that controlling shareholders, who often manage the firms that they control, can expropriate minority shareholders by increasing the level of their own compensation (Cheung, Stouraitis, \&Wong, 2005), we expect a positive relationship between majority ownership and executive compensation. 
We control for BoardSize, which is defined as the number of total board members since prior studies indicate that board size has a positive influence on executive compensation (Banghøj, Gabrielsen, Petersen, \& Plenborg, 2010; Maltocsy, Shan, \& Seethamraju, 2012; Ozkan, 2011). This positive influence may be due that larger boards are less effective in controlling management (Maltocsy et al., 2012) since the monitoring capacity is weakened and the actions become more dispersed on larger boards.

Other studies show that firm performance has a positive influence on executive compensation (Cheng \& Swenson, 2018; Conyon, 2014; Graham, Li e Qiu, 2011) since compensation is seen as an instrument to align managerial interests with those of the shareholders (Banghøj et al., 2010). In this way, considering that firms tie compensation to firm performance in order to maximize shareholder wealth, we control for Profitability, which is defined by the ratio of net income to total assets.

We control for Size, which is defined as the logarithm of net sales revenue, because larger firms have better conditions to pay higher levels of executive compensation due to the larger volume of business, which results in higher revenues and profits (Sridhar \& Kumar, 2015). Additionally, we include Leverage, defined as the ratio of total debt to total assets, since agency costs of debt in high leverage firms may be reduced by inducing lower levels of executive compensation (Ortiz-Molina, 2007). Thus, in line with prior evidence (Jiraporn et al., 2005; Lin, Kuo, \&Wang, 2013), we expect a negative relationship between leverage and executive compensation.

As a proxy for growth opportunities, we use Market-to-book, which is measured by the ratio of market value to total assets. Considering that firms with higher growth opportunities are more complex than the others, they will demand higher-quality managers with higher equilibrium wages (Core, Holthausen, \& Lacker, 1999; Jaiswall and Bhattacharyya, 2016). Thus, we expect a positive relationship between market-to-book and executive compensation.

Finally, in line with prior studies (Fahlenbrach, 2009; Jaiswall \& Bhattacharyya, 2016; Jiraporn et al., 2005; Ozkan, 2011; Souther, 2016), we also include year dummies to control for the possible time fixed effect.

\section{DESCRIPTIVE STATISTICS AND RESULTS}

\subsection{Descriptive statistics}

Panel A of Table 2 presents a statistical summary of the data. The average of fixed compensation is higher than variable compensation, which is consistent with the perspective that Brazilian executives prefer not to fully assume the risk of not reach the expected results. In this sense, the fixed part of Brazilians executive compensation tends to be larger than the variable part, unlike in the US context, where it is common that executive compensation has a large variable part, or even that it is totally variable (Anjos, Tavares, Monte, \& Lustosa, 2015).

Similar to the evidence provided by Portulhak, Theiss, Kühl and Colauto (2017), we identify that 55 non-financial Brazilian firms adopt poison pills, which represents $25 \%$ of the total sample. However, in a complementary way, we show that only 9 firms $(0,9 \%)$ include poison pills in the bylaws as an "eternity" clause, which cannot be removed.

On average, firms also present low profitability $(0,2 \%)$ and high leverage $(165 \%)$ levels. This may occur due to the Brazilian economic crisis during the period 2012-2017, as evidenced by Lopes, Costa, Carvalho and Castro (2016) and Barbosa (2017). However, although reducing this economic crisis, we find that the sample firms have, on average, growth opportunities, since the market-to-book is positive. 
Panel $B$ of Table 2 shows that the firms that are adopting poison pills are, in fact, more susceptible to hostile takeovers due to their ownership dispersion (dispersed or dominant ownership structure). The dispersed, dominant and concentrated ownership classification follow Anjos et al. (2015), which classifies this three categories as follows: (i) dispersed - equal or lower to $20 \%$, (ii) dominant - above $20 \%$ and equal or lower to $50 \%$ and, (iii) concentrated - above $50 \%$.

This evidence presented in Panel $B$ is consistent with our findings presented on Panel $C$ that most of the firms that adopt poison pills (91\%) are at the new market level of corporate governance, which one of the prerequisites is the $20 \%$ free float, allowing a higher possibility of takeovers. Thus, in line with Portulhak et al. (2017), our results show that poison pills are more prone to be adopted by Brazilian public firms listed in the new market level.

Table 2 - Descriptive analysis

Panel A: Descriptive statistics of equations 1 and 2 variables

\begin{tabular}{|c|c|c|c|c|c|}
\hline & $\mathrm{N}$ & Mean & Std. Dev. & Min. & Max. \\
\hline TotalCompensation & 1,377 & 12.022 & 12.565 & 0.002 & 89.881 \\
\hline FixedCompensation & 1,377 & 7.282 & 6.634 & 0.002 & 61.533 \\
\hline VariableCompensation & 1,377 & 5.042 & 7.112 & 0 & 65.082 \\
\hline PoisonPill & 1,377 & 0.250 & 0.433 & 0 & 1 \\
\hline EternityClause & 1,377 & 0.0980 & 0.297 & 0 & 1 \\
\hline MajorityOwnership & 1,377 & 0.4749 & 0.499 & 3 & 1 \\
\hline BoardSize & 1,377 & 7.448 & 3.111 & -11.188 & 18 \\
\hline Profitability & 1,377 & 0.002 & 0.357 & -3.352 & 2.217 \\
\hline Size & 1,377 & 7.231 & 1.961 & -883.283 & 12.728 \\
\hline Leverage & 1,377 & -1.650 & 49.807 & 495.883 \\
\hline Market-to-book & 1,377 & 3.518 & 45.230 & 0 & 1389.932 \\
\hline
\end{tabular}

Panel B: Distribution of firms by ownership concentration levels

\begin{tabular}{|c|c|c|c|c|}
\hline & Poison Pill Adopters & Poison Pill Non-adopters & & Fraction (\%) \\
\hline & $\mathrm{N}$ & Fraction (\%) & 89 & 8.624 \\
\hline Dispersed & 127 & 36.812 & 376 & 36.434 \\
\hline Dominant & 131 & 37.971 & 567 & 54.942 \\
\hline Concentrated & 87 & 25.217 & N & \\
\hline
\end{tabular}

Panel C: Distribution of firms by corporate governance levels

\begin{tabular}{|c|c|c|c|c|}
\hline & Poison Pill Adopters & Poison Pill Non-adopters & & Fraction (\%) \\
\hline N & Fraction (\%) & N & Fraction (\%) & 44.864 \\
\hline Non-listing premium & 21 & 6.087 & 463 & 15.116 \\
\hline Level 1 & 4 & 1.159 & 156 & 6.783 \\
\hline Level 2 & 6 & 1.739 & 70 & 33.236 \\
\hline New market & 314 & 91.014 & 343 & \\
\hline
\end{tabular}

Financial values are in Brazilian Real (BRL). See Appendix A for variable definitions.

Table 3 presents the correlation matrix coefficients, reporting the spearman, phi, or point-biserial correlation coefficients. Due to the non-normality of the variables (Shapiro-Wilk test), we perform Spearman correlations for two continuously measured variables; Phi correlations for two dichotomous variables; and Point-biserial correlation in situations with one continuous variable and one dichotomous variable.

The correlation of total compensation with anti-takeover measures shows that executives earn higher total compensation in firms that adopt poison pills and "eternity" clause poison pills. Additionally, executives earn higher total compensation in larger (board and size), more profitable and growth-oriented firms, but earn smaller compensation in more leverage firms. This result is similar to fixed compensation and variable compensation. 


\begin{tabular}{|c|c|c|c|c|c|c|c|c|c|c|c|c|}
\hline & & (1) & (2) & (3) & (4) & (5) & (6) & (7) & (8) & (9) & $(10)$ & (11) \\
\hline (1) & $\begin{array}{c}\text { Total Compensation } \\
\text { Fixed }\end{array}$ & 1 & & & & & & & & & & \\
\hline (2) & $\begin{array}{l}\text { Compensation } \\
\text { Variable }\end{array}$ & 0.944 & 1 & & & & & & & & & \\
\hline (3) & Compensation & 0.888 & 0.766 & 1 & & & & & & & & \\
\hline (4) & PoisonPill & 0.183 & 0.256 & 0.209 & 1 & & & & & & & \\
\hline$(5)$ & Eternity Clause & 0.061 & 0.166 & 0.114 & 0.570 & 1 & & & & & & \\
\hline (6) & MajorityOwnership & -0.111 & -0.107 & -0.133 & 0.257 & 0.196 & 1 & & & & & \\
\hline (7) & BoardSize & 0.398 & 0.383 & 0.362 & -0.080 & -0.058 & 0.040 & 1 & & & & \\
\hline (8) & Profitability & 0.184 & 0.156 & 0.183 & -0.032 & 0.028 & -0.030 & 0.083 & 1 & & & \\
\hline (9) & Leverage & -0.051 & -0.052 & -0.060 & -0.024 & -0.032 & 0.011 & -0.028 & -0.376 & 1 & & \\
\hline (10) & Size & 0.544 & 0.502 & 0.484 & 0.047 & -0.034 & 0.082 & 0.385 & 0.148 & 0.092 & 1 & \\
\hline (11) & Market-to-book & 0.293 & 0.276 & 0.283 & -0.006 & -0.003 & -0.021 & 0.209 & 0.214 & 0.246 & 0.318 & 1 \\
\hline
\end{tabular}

Bolded coefficients are statistically significant at $5 \%$ level. TotalCompensation is measured as the sum of the logarithms of fixed compensation, variable compensation and stock options exercised. FixedCompensation is measured as the sum of the logarithms of salary, fixed benefits, fixed participation and other fixed compensations. VariableCompensation is measured as the sum of the logarithms of bonus, results participation, meetings participation, commissions participation and other variable compensations. PoisonPill is an indicator variable that equals one if the firm has a poison pill, and zero otherwise. EternityClause is an indicator variable that equals one if the firm has an "eternity" clause poison pill, and zero otherwise. MajorityOwnership is an indicator variable that equals one if the firm has its largest shareholder with more than $50 \%$ of voting shares, and zero otherwise. BoardSize is the total board members. Profitability is the ratio of net income to total assets. Size is the logarithm of net sales revenue. Leverage is the ratio of total debt to total assets. Market-to-book is the ratio of market value to total assets.

Based on the correlation matrix coefficients, we find that there is no moderately high correlation between independent and control variables included in the econometric models, which suggests that there is no problem of multicollinearity. We identified that the independent variables PoisonPill and Eternity Clause present the only moderate and significant correlation. Thus, we do not include them simultaneously in equations 1 and 2 .

\subsection{Empirical results}

able 4 presents the estimation results for equation (1) in order to test our first hypothesis $(\mathrm{H} 1)$, which predicts that poison pills are positively associated with executive compensation. The regression specifications result in three groups. Panel A reports the results of the poison pills influence on total compensation. Panels $B$ and $C$ report the results using fixed compensation and variable compensation as alternative dependent variables.

Table 4 - Test of Hypothesis 1 - Poison Pills influence on Executive Compensation

Panel A: Total Compensation Model

\begin{tabular}{|c|c|c|c|c|c|}
\hline \multirow{2}{*}{ PoisonPill } & \multicolumn{5}{|c|}{ Dependent variable: TotalCompensation } \\
\cline { 2 - 6 } & $\mathrm{Q}(0.10)$ & $\mathrm{Q}(0.25)$ & $\mathrm{Q}(0.50)$ & $\mathrm{Q}(0.75)$ & $\mathrm{Q}(0.90)$ \\
\hline & $2.118^{* * *}$ & $3.069^{* * *}$ & $5.431^{* * *}$ & $4.781^{* * *}$ & $3.983^{* *}$ \\
\cline { 2 - 6 } & $(0.348)$ & $(0.481)$ & $(0.594)$ & $(1.135)$ & $(1.630)$ \\
\hline \multirow{3}{*}{ MajorityOwnership } & $-1.098^{* * *}$ & $-1.476^{* * *}$ & $-1.957^{* * *}$ & $-1.947^{* *}$ & -1.853 \\
\cline { 2 - 6 } & $(0.301)$ & $(0.416)$ & $(0.514)$ & $(0.981)$ & $(1.410)$ \\
\hline \multirow{3}{*}{ BoardSize } & $0.139^{* * *}$ & $0.247^{* * *}$ & $0.458^{* * *}$ & $1.265^{* * *}$ & $2.263^{* * *}$ \\
\cline { 2 - 6 } & $(0.051)$ & $(0.071)$ & $(0.088)$ & $(0.168)$ & $(0.241)$ \\
\hline \multirow{3}{*}{ Profitability } & $2.117^{* * *}$ & 0.915 & 0.231 & 0.640 & 1.263 \\
\cline { 2 - 6 } & $(0.409)$ & $(0.565)$ & $(0.698)$ & $(1.333)$ & $(1.916)$ \\
\hline \multirow{3}{*}{ Size } & $0.523^{* * *}$ & $0.934^{* * *}$ & $1.680^{* * *}$ & $2.334^{* * *}$ & $2.800^{* * *}$ \\
\cline { 2 - 6 } & $(0.082)$ & $(0.114)$ & $(0.141)$ & $(0.269)$ & $(0.387)$ \\
\hline \multirow{2}{*}{ Leverage } & 0.004 & -0.002 & -0.003 & -0.007 & -0.013 \\
\cline { 2 - 6 } & $(0.002)$ & $(0.004)$ & $(0.004)$ & $(0.009)$ & $(0.013)$ \\
\hline
\end{tabular}




\begin{tabular}{|c|c|c|c|c|c|}
\hline \multirow{2}{*}{ Market-to-book } & 0.003 & 0.008 & 0.004 & $0.019^{*}$ & 0.018 \\
\cline { 2 - 6 } & $(0.003)$ & $(0.004)$ & $(0.005)$ & $(0.010)$ & $(0.014)$ \\
\hline \multirow{3}{*}{ Constant } & $-2.916^{* * *}$ & $-4.612^{* * *}$ & $-8.283^{* * *}$ & $-13.095^{* * *}$ & $-17.169^{* * *}$ \\
\cline { 2 - 6 } & $(0.707)$ & $(0.977)$ & $(1.207)$ & $(2.304)$ & $(3.310)$ \\
\hline Year & Yes & Yes & Yes & Yes & Yes \\
\hline Pseudo R2 & 0.092 & 0.136 & 0.205 & 0.232 & 0.299 \\
\hline
\end{tabular}

The panel A of Table 4 reports the influence of Poison Pills on Total Compensation. The dependent variable is TotalCompensation, measured as the sum of the logarithms of fixed compensation, variable compensation and stock options exercised. PoisonPill is an indicator variable that equals one if the firm has a poison pill, and zero otherwise. MajorityOwnership is an indicator variable that equals one if the firm has its largest shareholder with more than $50 \%$ of voting shares, and zero otherwise. BoardSize is the total board members. Profitability is the ratio of net income to total assets. Size is the logarithm of net sales revenue. Leverage is the ratio of total debt to total assets. Market-to-book is the ratio of market value to total assets. Robust standard errors are reported in parentheses. ${ }^{*}, * * * * * *$ indicate significance at the $10 \%, 5 \%$, and $1 \%$ levels (two-tailed), respectively.

Panel B: Fixed Compensation Model

\begin{tabular}{|c|c|c|c|c|c|}
\hline \multirow{2}{*}{ PoisonPill } & \multicolumn{5}{|c|}{ Dependent variable: FixedCompensation } \\
\cline { 2 - 6 } & $\mathrm{Q}(0.10)$ & $\mathrm{Q}(0.25)$ & $\mathrm{Q}(0.50)$ & $\mathrm{Q}(0.75)$ & $\mathrm{Q}(0.90)$ \\
\hline & $1.425^{* * *}$ & $1.671^{* * *}$ & $2.695^{* * *}$ & $6.419^{* * *}$ & $6.332^{* * *}$ \\
\cline { 2 - 6 } & $(0.309)$ & $(0.302)$ & $(0.362)$ & $(0.605)$ & $(0.932)$ \\
\hline \multirow{3}{*}{ MajorityOwnership } & $-0.677^{* *}$ & $-0.998^{* * *}$ & $-0.743^{* *}$ & -0.779 & -0.354 \\
\cline { 2 - 6 } & $(0.267)$ & $(0.261)$ & $(0.313)$ & $(0.523)$ & $(0.806)$ \\
\hline \multirow{3}{*}{ BoardSize } & $0.117^{* *}$ & $0.138^{* * *}$ & $0.289^{* * *}$ & $0.602^{* * *}$ & $1.176^{* * *}$ \\
\cline { 2 - 6 } & $(0.045)$ & $(0.044)$ & $(0.053)$ & $(0.089)$ & $(0.138)$ \\
\hline \multirow{3}{*}{ Profitability } & $1.362^{* * *}$ & 0.087 & 0.245 & 0.688 & 1.029 \\
\cline { 2 - 6 } & $(0.363)$ & $(0.355)$ & $(0.425)$ & $(0.711)$ & $(1.095)$ \\
\hline \multirow{3}{*}{ Size } & $0.292^{* * *}$ & $0.660^{* * *}$ & $1.005^{* * *}$ & $1.068^{* * *}$ & $1.025^{* * *}$ \\
\cline { 2 - 6 } & $(0.073)$ & $(0.071)$ & $(0.086)$ & $(0.143)$ & $(0.221)$ \\
\hline \multirow{2}{*}{ Leverage } & 0.005 & -0.001 & -0.001 & -0.004 & -0.005 \\
\cline { 2 - 6 } & $(0.002)$ & $(0.002)$ & $(0.003)$ & $(0.005)$ & $(0.007)$ \\
\hline \multirow{2}{*}{ Constant } & 0.002 & 0.001 & 0.003 & 0.003 & 0.003 \\
\cline { 2 - 6 } & $(0.002)$ & $(0.002)$ & $(0.003)$ & $(0.005)$ & $(0.008)$ \\
\hline Year & $-1.463^{* *}$ & $-2.878^{* * *}$ & $-4.706^{* * *}$ & $-5.478^{* * *}$ & $-5.618^{* * *}$ \\
\hline Pseudo R2 & $(0.627)$ & $(0.613)$ & $(0.735)$ & $(1.230)$ & $(1.893)$ \\
\hline Yes & Yes & Yes & Yes & Yes \\
\hline & 0.101 & 0.154 & 0.213 & 0.257 & 0.276 \\
\hline
\end{tabular}

The panel B of Table 4 reports the influence of Poison Pills on Fixed Compensation. The dependent variable is FixedCompensation, measured as the sum of the logarithms of salary, fixed benefits, fixed participation and other fixed compensations. PoisonPill is an indicator variable that equals one if the firm has a poison pill, and zero otherwise. MajorityOwnership is an indicator variable that equals one if the firm has its largest shareholder with more than $50 \%$ of voting shares, and zero otherwise. BoardSize is the total board members. Profitability is the ratio of net income to total assets. Size is the logarithm of net sales revenue. Leverage is the ratio of total debt to total assets. Market-to-book is the ratio of market value to total assets. Robust standard errors are reported in parentheses. ${ }^{*}, * * * * * *$ indicate significance at the $10 \%, 5 \%$, and $1 \%$ levels (two-tailed), respectively.

Panel C: Variable Compensation Model

\begin{tabular}{|c|c|c|c|c|c|}
\hline & \multicolumn{5}{|c|}{ Dependent variable: VariableCompensation } \\
\cline { 2 - 6 } & $\mathrm{Q}(0.10)$ & $\mathrm{Q}(0.25)$ & $\mathrm{Q}(0.50)$ & $\mathrm{Q}(0.75)$ & $\mathrm{Q}(0.90)$ \\
\hline \multirow{3}{*}{ PoisonPill } & $0.136^{* *}$ & $1.390^{* * *}$ & $2.436^{* * *}$ & $6.462^{* * *}$ & $6.427^{* * *}$ \\
\cline { 2 - 6 } & $(0.059)$ & $(0.190)$ & $(0.334)$ & $(0.930)$ & $(1.011)$ \\
\hline \multirow{3}{*}{ MajorityOwnership } & -0.034 & $-0.405^{* *}$ & $-0.973^{* * *}$ & -0.607 & $-1.589^{*}$ \\
\cline { 2 - 6 } & $(0.051)$ & $(0.164)$ & $(0.289)$ & $(0.804)$ & $(0.874)$ \\
\hline \multirow{3}{*}{ BoardSize } & $0.017^{* *}$ & $0.066^{* *}$ & $0.167^{* * *}$ & $0.484^{* * *}$ & $1.471^{* * *}$ \\
\cline { 2 - 6 } & $(0.008)$ & $(0.028)$ & $(0.049)$ & $(0.138)$ & $(0.150)$ \\
\hline \multirow{3}{*}{ Profitability } & 0.041 & 0.305 & -0.023 & 0.596 & 0.095 \\
\cline { 2 - 6 } & $(0.069)$ & $(0.223)$ & $(0.392)$ & $(1.093)$ & $(1.188)$ \\
\hline
\end{tabular}




\begin{tabular}{|c|c|c|c|c|c|}
\hline \multirow{2}{*}{ Size } & 0.022 & $0.183^{* * *}$ & $0.644^{* * *}$ & $0.912^{* * *}$ & $1.038^{* * *}$ \\
\cline { 2 - 6 } & $(0.014)$ & $(0.045)$ & $(0.079)$ & $(0.221)$ & $(0.240)$ \\
\hline \multirow{2}{*}{ Leverage } & -0.001 & -0.001 & -0.002 & -0.001 & -0.008 \\
\cline { 2 - 6 } & $(0.001)$ & $(0.001)$ & $(0.002)$ & $(0.007)$ & $(0.008)$ \\
\hline \multirow{2}{*}{ Market-to-book } & 0.003 & 0.005 & 0.003 & 0.010 & 0.010 \\
\cline { 2 - 6 } & $(0.005)$ & $(0.001)$ & $(0.003)$ & $(0.008)$ & $(0.009)$ \\
\hline \multirow{2}{*}{ Constant } & $-0.259^{* *}$ & $-1.333^{* * *}$ & $-3.586^{* * *}$ & $-5.514^{* * *}$ & $-8.404^{* * *}$ \\
\cline { 2 - 6 } & $(0.120)$ & $(0.386)$ & $(0.678)$ & $(1.889)$ & $(2.054)$ \\
\hline Year & Yes & Yes & Yes & Yes & Yes \\
\hline Pseudo R2 & 0.001 & 0.056 & 0.135 & 0.176 & 0.232 \\
\hline
\end{tabular}

The panel C of Table 4 reports the influence of Poison Pills on Variable Compensation. The dependent variable is VariableCompensation, measured as the sum of the logarithms of bonus, results participation, meetings participation, commissions participation and other variable compensations. PoisonPill is an indicator variable that equals one if the firm has a poison pill, and zero otherwise. MajorityOwnership is an indicator variable that equals one if the firm has its largest shareholder with more than $50 \%$ of voting shares, and zero otherwise. BoardSize is the total board members. Profitability is the ratio of net income to total assets. Size is the logarithm of net sales revenue. Leverage is the ratio of total debt to total assets. Market-to-book is the ratio of market value to total assets. Robust standard errors are reported in parentheses. ${ }^{* * * * * * * * *}$ indicate significance at the 10\%, 5\%, and 1\% levels (two-tailed), respectively.

Panel A of Table 4 shows that PoisonPill coefficients are significantly positive for TotalCompensation in all quantiles. Panels $B$ and $C$ show that these positive significant coefficients of PoisonPill are robust to FixedCompensation and VariableCompensation models. Furthermore, in comparison with the base group (firms who not adopt poison pills), we identify that firms who adopt poison pills pay higher levels of executive compensation those who do not adopt this anti-takeover defense. These results support our first hypothesis, which predicts that poison pills are positively associated with executive compensation.

Our evidence that firms that adopt poison pills pay higher levels of executive compensation is consistent with the managerial entrenchment hypothesis, which considers that once an anti-takeover defense has been adopted, entrenched managers may use the protection provided by this mechanism to obtain contracts that further increase the level of their compensation (Borokhovich et al., 1997).

Hence, our findings corroborate previous studies (Borokhovich et al., 1997; Chakraborty \& Sheikh, 2010; Fahlenbrach, 2009; Jiraporn et al., 2005; Souther, 2016) who shows that there is a positive and significant association between anti-takeover defenses and executive compensation.

The coefficients of MajorityOwnership are significantly negative in the Panel A, except for quantile 0.90 , which coefficient is negative but not significant, suggesting that a controlling stake does not influence firms with higher levels of executive compensation. This significant and negative association between MajorityOwnership and TotalCompensation in most quantiles opposes the perspective that controlling shareholders, who often manage the firms that they control, can increase their own compensation at the expense of shareholders (Cheung et al., 2005).

However, Lin et al., (2013) and Lin and Lin (2014) explain this negative association, arguing that majority concentration may propitiate stronger incentives to boost the firm's stock value. Therefore, lower levels of executive compensation are needed for aligning the interests between managers and shareholders.

Panels B and C of Table 4 shows mixed evidence. While MajorityOwnership also becomes non-significant in the quantile 0.75 in the Panel B, broadening to fixed compensation the perspective that a controlling stake is not positively associated with higher levels of executive compensation, the Panel C presents inconclusive results due to the variability of the significance.

The positive coefficients of BoardSize in the Panels A, B, and C confirm our predictions that the monitoring capacity is weakened and the actions become dispersed on larger boards, allowing executives to exercise greater influence over their remuneration. An additional explanation that also applies to Brazilian 
firms is provided by Ozkan (2011), who argues that in a setting where the compensation contract is not optimally designed, board characteristics are expected to affect the level of executive compensation.

This results corroborates international findings (Banghøj et al., 2010; Lin \& Lin, 2014; Maltocsy et al., 2012) and brings new evidence on Brazilian context, since prior studies (Anjos et al., 2015; Cunha, Vogt, \& Degenhart, 2016) did not find a positive association between board size and executive compensation. This difference to the Brazilian studies may be due that we analyze a larger number of companies as well as a more extented period.

Panels A, B and C of Table 4 reports similar positive and significant results for Size, showing that larger firms pay higher levels of executive compensation on all quantiles of TotalCompensation, FixedCompensation and VariableCompensation models, except on quantile 0.10 of VariableCompensation.

We offer two possible explanations for this non-significance on quantile 0.10 . First, considering that firms in this quantile present lower levels of net sales revenue (proxy for size), these firms may be not paying variable compensation to their executives due to the lower volume of business. Additionally, it may be due to the absence of variable compensation in several firms of this quantile, which evidence that several Brazilian companies not incentive their executives with variable compensation.

We find inconclusive results that firms' performance has a positive influence on executive compensation since Profitability presents a significant association only on the quantile 0.10 of TotalCompensation and FixedCompensation models. However, it is possible that the model not capture this relationship due to the low profitability average (0.002) of our sample companies, as shown in Table 2.

Finally, there is no evidence that Leverage and Market-to-book explain executive compensation since the coefficients of these control variables are non-significant. Time dummies coefficients are not reported, as they are not of direct interest in this study.

In an exploratory way, since the poison pills can be included in the Brazilian companies bylaws as an "eternity" clause, we test our second hypothesis ( $(\mathrm{H} 2)$, which predicts that "eternity" clause poison pills are positively associated with executive compensation. Table 5 presents the estimation results for equation (2). Panel A reports the results of the "eternity" clause influence on total compensation. Panels B and C report the results using fixed compensation and variable compensation as alternative dependent variables.

Table 5 - Test of Hypothesis 2 - "Eternity" Clause Poison Pills influence on Executive Compensation Panel A: Total Compensation Model

\begin{tabular}{|c|c|c|c|c|c|}
\hline \multirow{2}{*}{} & \multicolumn{5}{|c|}{ Dependent variable: TotalCompensation } \\
\cline { 2 - 6 } & $\mathrm{Q}(0.10)$ & $\mathrm{Q}(0.25)$ & $\mathrm{Q}(0.50)$ & $\mathrm{Q}(0.75)$ & $\mathrm{Q}(0.90)$ \\
\hline \multirow{3}{*}{ EternityClause } & $2.205^{* * *}$ & $2.696^{* * *}$ & $5.722^{* * *}$ & $4.096^{* *}$ & 3.179 \\
\cline { 2 - 6 } & $(0.468)$ & $(0.620)$ & $(0.938)$ & $(1.721)$ & $(2.543)$ \\
\hline \multirow{3}{*}{ MajorityOwnership } & $-1.203^{* * *}$ & $-1.847^{* * *}$ & $-2.491^{* * *}$ & $-2.448^{* *}$ & $-2.913^{*}$ \\
\cline { 2 - 6 } & $(0.279)$ & $(0.370)$ & $(0.560)$ & $(1.027)$ & $(1.518)$ \\
\hline \multirow{3}{*}{ BoardSize } & $0.129^{* * *}$ & $0.221^{* * *}$ & $0.402^{* * *}$ & $1.238^{* * *}$ & $2.307^{* * *}$ \\
\cline { 2 - 6 } & $(0.048)$ & $(0.064)$ & $(0.097)$ & $(0.178)$ & $(0.263)$ \\
\hline \multirow{2}{*}{ Profitability } & $1.364^{* * *}$ & 0.406 & -0.187 & 0.233 & 1.050 \\
\cline { 2 - 6 } & $(0.386)$ & $(0.512)$ & $(0.774)$ & $(1.420)$ & $(2.098)$ \\
\hline \multirow{2}{*}{ Size } & $0.547^{* * *}$ & $1.013^{* * *}$ & $2.092^{* * *}$ & $2.451^{* * *}$ & $2.967^{* * *}$ \\
\cline { 2 - 6 } & $(0.077)$ & $(0.112)$ & $(0.155)$ & $(0.285)$ & $(0.421)$ \\
\hline \multirow{2}{*}{ Leverage } & 0.001 & -0.002 & -0.003 & -0.010 & -0.015 \\
\cline { 2 - 6 } & $(0.002)$ & $(0.003)$ & $(0.005)$ & $(0.010)$ & $(0.014)$ \\
\hline \multirow{2}{*}{ Market-to-book } & 0.002 & 0.001 & 0.009 & 0.017 & 0.011 \\
\cline { 2 - 6 } & $(0.003)$ & $(0.004)$ & $(0.006)$ & $(0.011)$ & $(0.016)$ \\
\hline
\end{tabular}




\begin{tabular}{|c|c|c|c|c|c|}
\hline \multirow{2}{*}{ Constant } & $-2.621^{* * *}$ & $-4.724^{* * *}$ & $-9.819^{* * *}$ & $-13.280^{* * *}$ & $-16.443^{* * *}$ \\
\cline { 2 - 6 } & $(0.670)$ & $(0.887)$ & $(1.342)$ & $(2.461)$ & $(3.636)$ \\
\hline Year & Yes & Yes & Yes & Yes & Yes \\
\hline Pseudo R2 & 0.087 & 0.127 & 0.187 & 0.222 & 0.295 \\
\hline
\end{tabular}

The panel A of Table 5 reports the influence of "Eternity" Clause Poison Pills on Total Compensation. The dependent variable is TotalCompensation, measured as the sum of the logarithms of fixed compensation, variable compensation and stock options exercised. EternityClause is an indicator variable that equals one if the firm has an "eternity" clause poison pill, and zero otherwise. MajorityOwnership is an indicator variable that equals one if the firm has its largest shareholder with more than $50 \%$ of voting shares, and zero otherwise. BoardSize is the total board members. Profitability is the ratio of net income to total assets. Size is the logarithm of net sales revenue. Leverage is the ratio of total debt to total assets. Market-to-book is the ratio of market value to total assets. Robust standard errors are reported in parentheses. ${ }^{*}, * * *, * * *$ indicate significance at the $10 \%$, $5 \%$, and $1 \%$ levels (two-tailed), respectively.

Panel B: Fixed Compensation Model

\begin{tabular}{|c|c|c|c|c|c|}
\hline & \multicolumn{5}{|c|}{ Dependent variable: FixedCompensation } \\
\hline & $\mathrm{Q}(0.10)$ & $\mathrm{Q}(0.25)$ & $\mathrm{Q}(0.50)$ & $Q(0.75)$ & $\mathrm{Q}(0.90)$ \\
\hline \multirow{2}{*}{ EternityClause } & $1.921^{* * *}$ & $1.998^{* * *}$ & $3.355^{* * *}$ & $7.018^{* * *}$ & $5.725^{* * *}$ \\
\hline & $(0.478)$ & $(0.427)$ & $(0.510)$ & $(0.656)$ & $(1.360)$ \\
\hline \multirow{2}{*}{ MajorityOwnership } & $-0.840^{* * *}$ & $-1.231^{* * *}$ & $-0.962^{* * *}$ & $-1.292^{* * *}$ & -0.931 \\
\hline & $(0.285)$ & $(0.255)$ & $(0.304)$ & $(0.392)$ & $(0.812)$ \\
\hline \multirow{2}{*}{ BoardSize } & $0.111^{* *}$ & $0.123^{* * *}$ & $0.244^{* * *}$ & $0.537^{* * *}$ & $1.361^{* * *}$ \\
\hline & $(0.049)$ & $(0.044)$ & $(0.052)$ & $(0.068)$ & $(0.141)$ \\
\hline \multirow{2}{*}{ Profitability } & $0.672^{*}$ & 0.049 & 0.013 & 0.321 & 0.496 \\
\hline & $(0.394)$ & $(0.352)$ & $(0.421)$ & $(0.542)$ & $(1.122)$ \\
\hline \multirow{2}{*}{ Size } & $0.348^{* * *}$ & $0.747^{* * *}$ & $1.131^{* * *}$ & $1.307^{* * *}$ & $1.176^{* * *}$ \\
\hline & $(0.079)$ & $(0.070)$ & $(0.084)$ & $(0.108)$ & $(0.225)$ \\
\hline \multirow{2}{*}{ Leverage } & 0.001 & -0.001 & -0.001 & -0.006 & -0.007 \\
\hline & $(0.002)$ & $(0.002)$ & $(0.002)$ & $(0.003)$ & $(0.007)$ \\
\hline \multirow{2}{*}{ Market-to-book } & 0.002 & 0.005 & 0.002 & 0.004 & -0.001 \\
\hline & $(0.003)$ & $(0.002)$ & $(0.003)$ & $(0.004)$ & $(0.008)$ \\
\hline \multirow{2}{*}{ Constant } & $-1.684^{* *}$ & $-3.126^{* * *}$ & $-5.114^{* * *}$ & $-5.876^{* * *}$ & $-6.288^{* * *}$ \\
\hline & $(0.683)$ & $(0.611)$ & $(0.730)$ & $(0.939)$ & (1.944) \\
\hline Year & Yes & Yes & Yes & Yes & Yes \\
\hline Pseudo R2 & 0.099 & 0.150 & 0.204 & 0.243 & 0.241 \\
\hline
\end{tabular}

The panel B of Table 5 reports the influence of "Eternity" Clause Poison Pills on Fixed Compensation. The dependent variable is FixedCompensation, measured as the sum of the logarithms of salary, fixed benefits, fixed participation and other fixed compensations. EternityClause is an indicator variable that equals one if the firm has an "eternity" clause poison pill, and zero otherwise. MajorityOwnership is an indicator variable that equals one if the firm has its largest shareholder with more than $50 \%$ of voting shares, and zero otherwise. BoardSize is the total board members. Profitability is the ratio of net income to total assets. Size is the logarithm of net sales revenue. Leverage is the ratio of total debt to total assets. Market-to-book is the ratio of market value to total assets. Robust standard errors are reported in parentheses. ${ }^{*}, * * * * * * *$ indicate significance at the $10 \%$, $5 \%$, and $1 \%$ levels (two-tailed), respectively.

Panel C: Variable Compensation Model

\begin{tabular}{|c|c|c|c|c|c|}
\hline \multirow{2}{*}{} & \multicolumn{5}{|c|}{ Dependent variable:VariableCompensation } \\
\cline { 2 - 6 } & $\mathrm{Q}(0.10)$ & $\mathrm{Q}(0.25)$ & $\mathrm{Q}(0.50)$ & $\mathrm{Q}(0.75)$ & $\mathrm{Q}(0.90)$ \\
\hline \multirow{3}{*}{ EternityClause } & $0.206^{* * *}$ & $0.884^{* * *}$ & $2.284^{* * *}$ & $8.800^{* * *}$ & $5.945^{* * *}$ \\
\cline { 2 - 6 } & $(0.074)$ & $(0.274)$ & $(0.471)$ & $(1.110)$ & $(1.533)$ \\
\hline \multirow{3}{*}{ MajorityOwnership } & -0.020 & $-0.489^{* * *}$ & $-1.356^{* * *}$ & $-1.308^{* *}$ & $-2.577^{* * *}$ \\
\cline { 2 - 6 } & $(0.044)$ & $(0.163)$ & $(0.281)$ & $(0.663)$ & $(0.915)$ \\
\hline \multirow{3}{*}{ BoardSize } & $0.012^{*}$ & $0.062^{* *}$ & $0.161^{* * *}$ & $0.511^{* * *}$ & $1.399^{* * *}$ \\
\cline { 2 - 6 } & $(0.007)$ & $(0.028)$ & $(0.048)$ & $(0.115)$ & $(0.159)$ \\
\hline \multirow{2}{*}{ Profitability } & 0.028 & 0.315 & -0.111 & -0.022 & 0.118 \\
\cline { 2 - 6 } & $(0.061)$ & $(0.226)$ & $(0.389)$ & $(0.916)$ & $(1.265)$ \\
\hline
\end{tabular}




\begin{tabular}{|c|c|c|c|c|c|}
\hline \multirow{2}{*}{ Size } & 0.014 & $0.213^{* * *}$ & $0.790^{* * *}$ & $1.128^{* * *}$ & $1.066^{* * *}$ \\
\cline { 2 - 6 } & $(0.012)$ & $(0.045)$ & $(0.078)$ & $(0.184)$ & $(0.254)$ \\
\hline \multirow{2}{*}{ Leverage } & -0.001 & -0.001 & -0.002 & -0.001 & -0.010 \\
\cline { 2 - 6 } & $(0.004)$ & $(0.001)$ & $(0.002)$ & $(0.006)$ & $(0.008)$ \\
\hline \multirow{2}{*}{ Market-to-book } & 0.003 & 0.003 & 0.004 & 0.008 & 0.013 \\
\cline { 2 - 6 } & $(0.004)$ & $(0.001)$ & $(0.003)$ & $(0.007)$ & $(0.009)$ \\
\hline \multirow{2}{*}{ Constant } & -0.170 & $-1.443^{* * *}$ & $-4.140^{* * *}$ & $-6.345^{* * *}$ & $-7.389^{* * *}$ \\
\cline { 2 - 6 } & $(0.106)$ & $(0.392)$ & $(0.674)$ & $(1.588)$ & $(2.193)$ \\
\hline Year & Yes & Yes & Yes & Yes & Yes \\
\hline Pseudo R2 & 0.001 & 0.046 & 0.123 & 0.179 & 0.213 \\
\hline
\end{tabular}

The panel C of Table 5 reports the influence of "Eternity" Clause Poison Pills on Variable Compensation. The dependent variable is VariableCompensation, measured as the sum of the logarithms of bonus, results participation, meetings participation, commissions participation and other variable compensations. EternityClause is an indicator variable that equals one if the firm has an "eternity" clause poison pill, and zero otherwise. MajorityOwnership is an indicator variable that equals one if the firm has its largest shareholder with more than $50 \%$ of voting shares, and zero otherwise. BoardSize is the total board members. Profitability is the ratio of net income to total assets. Size is the logarithm of net sales revenue. Leverage is the ratio of total debt to total assets. Market-to-book is the ratio of market value to total assets. Robust standard errors are reported in parentheses. *********indicate significance at the 10\%, 5\%, and 1\% levels (two-tailed), respectively.

Panel A of Table 5 shows that EternityClause coefficients are significantly positive for TotalCompensation in all quantiles, with the exception of quantile 0.90 . Nevertheless, Panels $B$ and $C$ brings interesting results, showing that the adoption of "eternity" clause poison pills influence positively and significantly on FixedCompensation and VariableCompensation in all quantiles. The non-significance of quantile 0.90 on TotalCompensation model may occur due to the low number of firms in this quantile that adopt this type of anti-takeover device, in comparison with the firms included on quantile 0.90 of FixedCompensation and VariableCompensation models.

Similar to Table 4 results, the group base (firms who not adopt "eternity" clause poison pills) coefficients are negative, which suggests that firms who adopt "eternity" clause poison pills pay higher levels of executive compensation those who do not adopt this "eternity" clause. These overall findings support our second hypothesis, which predicts that "eternity" poison pills are positively associated with executive compensation.

In this sense, corroborating Martins (2015), who argue that poison pills in Brazil maintaining managers privileges in the detriment of minority shareholders, including increases in the executive compensation levels, we suggest that this particularity of "eternity" clause in Brazilian bylaws leads to a managerial entrenchment, and consequently in an increase in the executive compensation levels.

Turning to the control variables, all coefficients of MajorityOwnership reported on Panel A of Table 5 are significantly negative, corroborating prior evidence that majority concentration leads to lower levels of TotalCompensation (Conyon, 2011; Jiraporn et al., 2005; Fahlenbrach, 2009). However, in Panels $B$ and $C$ of Table 5, we identify mixed findings in firms with higher (lower) levels of fixed (variable) compensation, respectively.

On Panel B, our results suggest that MajorityOwnership does not influence significantly on firms with high levels of FixedCompensation (quantile 0.90), while Panel C reports similar non-significance between MajorityOwnership and firms with lower levels of VariableCompensation (quantile 0.10).

This findings may shed a light in previous evidence that there is no significant association between ownership concentration and fixed or variable executive compensation in the Brazilian context (Beuren, Moura, \& Theiss, 2016; Correia, Amaral, \& Louvet, 2014), since the possible presence of outliers (firms in quantiles 0.10 and 0.90 of our sample) may be influencing the models estimations in these studies. 
The BoardSize coefficients reported on Panel A are significantly positive for TotalCompensation in all quantiles. Furthermore, Panels $B$ and $C$ show that the coefficients of BoardSize are also significant and on the expected sign to FixedCompensation and VariableCompensation models, which confirms the perspective that board structure plays a relevant role in executive compensation (Maltocsy et al., 2012).

In line with prior evidences that larger firms pay higher levels of executive compensation (Chakraborty \& Sheikh, 2010; Conyon, 2011; Fahlenbrach, 2009; Jaiswall \& Bhattacharyya, 2016), the coefficients of Size are positive and significant in all quantiles of TotalCompensation, FixedCompensation and VariableCompensation models, except on quantile 0.10 of VariableCompensation.

As explained in the analysis of Table 4, this non-significance on quantile of 0.10 may be due to firms in this quantile are not paying variable compensation to their executives due the lower volume of business, or may be due to the absence of variable compensation in several firms of this quantile, considering that some Brazilian companies not incentive their executives with variable compensation.

Once again, Profitability provides inconclusive and similar results presented in Table 4. However, as explained earlier, the low profitability average (0.002) of our sample companies may be leading to this non-influence in almost all quantiles. Furthermore, Panels A, B and C of Table 5 shows that Leverage and Market-to-book coefficients are not significantly different from zero. Thus, our findings do not support that these control variables influence TotalCompensation, FixedCompensation or VariableCompensation.

Finally, in order to test if the coefficients of all models presented in Tables 4 and 5 are statistically different between the quantiles, we perform the Wald test, in which the null hypothesis is that the coefficients are equal to each other. The estimation results are presented in Appendix B.

Based on Wald test results, we reject the null hypothesis that the PoisonPill coefficients are equal to each other across all estimations. A similar result is found for the EternityClause. Thus, our results show that the effect of these variables on executive compensation are different between the quantiles since their coefficients present statistically significant differences between quantiles $0.10,0.25,0.50,0.75$ and 0.90, as shown in Figure 1.
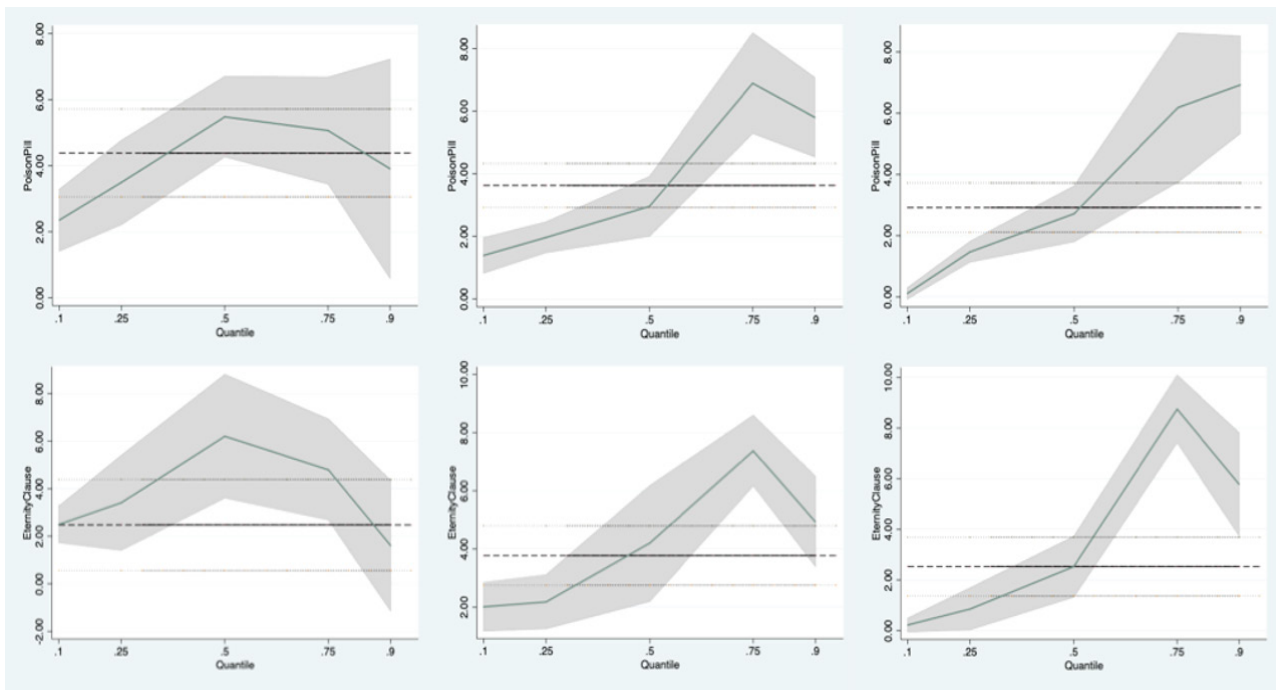

Figure 1 - Executive compensation, poison pills, and "eternity" poison pills - quantile estimates

Notes: $Y$-axis is the poison pills (above) or "eternity" poison pills (under). X-axis is quantile of total (left), fixed (center) or variable (right) executive compensation. The horizontal dashed line is the ordinary least square (OLS) estimated coefficient. The connected line in the shaded (confidence level) region is the separate quantile regression estimates. 
In addition, we identify that BoardSize and Size coefficients are also significant in all specifications of Models 1 and 2, and that MajorityOwnership is significant in some specifications, indicating that there are significant differences between their coefficients.

4.3 Testing for simultaneity

Although previous literature does not test the possible simultaneity between anti-takeover defenses and executive compensation (Borokhovich et al., 1997; Chakraborty \& Sheikh, 2010; Fahlenbrach, 2009; Jiraporn et al., 2005; Souther, 2016), the endogeneity problem remains a concern in our analyses since the anti-takeover adoption may lead to higher compensation levels, or intended higher compensation levels may lead to the adoption of anti-takeover defenses (Souther, 2016). Thus, considering that the poison pill adoption is not exogenous, but endogenous to firm characteristics (Nguyen, 2017), we perform endogeneity tests in order to examine the possible simultaneity between poison pills and executive compensation.

First, we perform a Two-Stage Least Squares (IV-2SLS) using lagged variables as instrumental variables for PoisonPill and EternityClause and robust standard errors since the Pagan-hall test for heteroskedasticity in instrumental variable models lead to rejecting the null hypothesis that disturbances are homoscedastic. The results are consistent with our prior evidence that PoisonPill and EternityClause are positively and significantly associated with executive compensation across all the models.

However, the Hansen's $J$ test for overidentifying restriction indicates that the lagged instruments are not statistically relevant across some specifications, considering the significant p-values at a $5 \%$ level, which leads to rejecting the null hypothesis that the structural models were specified correctly and that the instruments are valid across the models. Similar invalid lagged instruments were obtained when we perform dynamic panels (System-GMM), the Sargan test of overidentifying restrictions rejects the null hypothesis that overidentifying restrictions are valid across all estimations.

In this vein, considering that the lagged variables are not valid instruments and that, to the best of our knowledge, there is no previous study that indicates alternative instrumental variables to mitigate the possible simultaneity between poison pills and executive compensation, we examine whether Leverage and Market-to-book can be used as instrumental variables.

Our intuition to use these variables is based on the previous literature which use Leverage and Market-to-book to explain poison pill adoptions (Arikawa \& Mitsuada, 2011; Heron \& Lie, 2006). Furthermore, we consider that there is no association between these variables and executive compensation since our results show that there is no significant effect of Leverage and Market-to-book on executive compensation proxies across all estimations (Tables 4 and 5).

In unreported results, the test of overidentifying restriction indicates that the structural models were specified correctly and that Leverage and Market-to-book are valid instruments ( $p$-values higher than 5\%) across all IV-2SLS and IV-GMM estimations. We use the IV-2SLS model robust to standard errors due to the presence of heteroskedasticity (the Pagan-hall test for heteroskedasticity in instrumental variable models lead to rejecting the null hypothesis that disturbances are homoskedastic). Additionally, in a robustness way, we also perform the IV-GMM regressions.

However, across all estimations, the test of endogeneity leads not to reject the null hypothesis that PoisonPill and EternityClause are exogenous since the $p$-values are higher than $5 \%$ (both in IV-2SLS and IV-GMM models). In this sense, although the literature suggests that the poison pill adoption is 
not exogenous (Nguyen, 2017) and that anti-takeover defenses may be endogenous to executive compensation (Souther, 2016), our tests do not indicate the presence of endogeneity in our estimations.

\section{CONCLUSIONS}

This paper contributes to the literature on executive compensation by showing that managers of firms that adopt poison pills enjoy higher levels of total compensation than managers of companies that do not adopt this anti-takeover device. Furthermore, we identify that this finding is robust to fixed and variable executive compensation models.

These results are consistent with the entrenchment perspective that the adoption of anti-takeover defenses exacerbates the executive compensation levels, supporting our first hypothesis that poison pills are positively associated with executive compensation.

Furthermore, in an exploratory way, overall results show that this positive influence also persists when we test the effect of Brazilian "eternity" poison pills on the executive compensation proxies. This finding supports our second hypothesis that "eternity" clause poison pills are positively associated with executive compensation.

In this sense, we shed more light on factors that exacerbate agency costs by showing that although reducing the risk of a hostile takeover, poison pills are incurring in an additional agency cost for shareholders.

However, we point out that these additional agency costs not always leading to a reduction of conflicts between managers and shareholders since poison pills and the "eternity" poison pills seem not being adopted in the Brazilian context to benefit the shareholders, but to protect managers in their positions. Thus, protected in their positions, managers may obtain private benefits at the expense of shareholders, such as higher levels of executive compensation.

This potential obtaining of private benefits may explain prior literature that shareholders react negatively to poison pills adoption and that poisons pill reduce stockholder wealth. However, the markets' reaction to poison pill adoption is not examined in our research, being an avenue that can be explored by further studies in the Brazilian context, especially due to the negative markets' expectation varies according to different structures of board composition (Brickley, Coles, \& Terry, 1994).

Despite the contributions made, our paper also has its limitations. For instance, the non-random sample and composed only by Brazilian firms. In this sense, we encourage new studies exploring the influence of poison pills on executive compensation in other contexts, since publicly-traded firms of other countries also adopt this anti-takeover defense (e.g. Canada, South Korea, France, Italy, Russia and Japan).

Further research can also go beyond and explore corporate governance mechanisms that may play a role in poison pills adoption or in reducing (increasing) the influence of poison pills on executive compensation as moderators factors, such as institutional investors, board independence and analyst following (CEO duality and CEO as a member of the compensation committee).

REFERENCES

Ambrozini, M. A., Pimenta, T. Jr., \& Gaio, L. E. (2015). As pílulas de veneno: cláusulas em estatutos sociais de empresas para dificultar o takeover hostil. Revista de Administração IMED, 5(1), 59-69. 
Anjos, L. C. M., Tavares, M. F. N., Monte, P. A., \& Lustosa, P. R. B. (2015). Relações entre controle acionário e remuneração de executivos. Enfoque: Reflexão Contábil, 34(1),45-56.

Arikawa, Y., \& Mitsuada, Y. (2011). The adoption on poison pills and managerial entrechment: Evidence from Japan. Japan and the World Economy, 23(1), 63-77.

Banghøj, J., Gabrielsen, G., Petersen, C., \& Plenborg, T. (2010). Determinants of executive compensation in privately held firms. Accounting \& Finance, 50(3), 481-510.

Barbosa, F. H. Fo. (2017). A crise econômica de 2014/2017. Estudos Avançados, 31(89), 51-60.

Bereskin, F. L., \& Cicero, D. C. (2013). CEO compensation contagion: Evidence from an exogenous shock. Journal of Financial Economics, 107(2), 477-493.

Berle, A., \& Means, G. (1932). The modern corporation and private property. New York: Macmillan.

Beuren, I. M., Moura, G. D., \&Theiss, V. (2016). Remuneração dos Executivos em Empresas que Realizaram Combinação de Negócios. Revista de Administração da UNIMEP, 14(2), 1-30.

Bhaumik, S. K., \& Selarka, E. (2012). Does ownership concentration improve M\&A outcomes in emerging markets? Journal of Corporate Finance, 18(4), 717-726.

Borokhovich, K. A., Brunarski, K. R., \& Parrino, R. (1997). CEO Contracting and Antitakeover Amendments. The Journal of Finance, 52(4), 1495-1517.

Brickley, J. A., Coles, J. L., \& Terry, R. L. (1994). Outside directors and the adoption of poison pills. Journal of Financial Economics, 35(3), 371-390.

Chakraborty, A., \& Sheikh, S. (2010). Antitakeover Amendments and Managerial Entrenchment: New Evidence from Investment Policy and CEO Compensation. Quarterly Journal of Finance and Accounting, 49(1), 81-104.

Cheng, S., \& Indjejikian, R. J. (2009). The Market for Corporate Control and CEO Compensation: Complements or Substitutes? Contemporary Accounting Research, 26(3), 701-728.

Cheng, Q., \& Swenson, L. (2018). Executive compensation and cash contributions to defined benefit pension plans. Journal of Business Finance \& Accounting, 45(9-10), 1224-1259.

Cheung, Y., Stouraitis, A., \& Wong, A. W. S. (2005). Ownership concentration and executive compensation in closely held firms: Evidence from Hong Kong. Journal of Empirical Finance, 12(4), 511-532.

Conyon, M. J. (2014). Executive Compensation and Board Governance in US Firms. The Economic Journal, 124(574), 60-89.

Conyon, M. J., \& He, L. (2011). Executive compensation and corporate governance in China. Journal of Corporate Finance, 17(4), 1158-1175.

Conyon, M. J., \& He, L. (2017). Firm performance and boardroom gender diversity: A quantile regression approach. Journal of Business Research, 79, 198-211.

Core, J. E., Holthausen, R. W., \& Larcker, D. F. (1999). Corporate governance, chief executive officer compensation, and firm performance. Journal of Financial Economics, 51(3), 371-406.

Correia, L. F., Amaral, H. F., \& Louvet, P. (2014). Remuneração, composição do conselho de administração e estrutura de propriedade: Evidências empíricas do mercado acionário brasileiro. Advances in Scientific and Applied Accounting, 7(1), 2-37. 
Cunha, P. R., Vogt, M., \& Degenhart, L. (2016). Governança corporativa e remuneração dos diretores executivos dasempresas Brasileiras. Enfoque: Reflexão Contábil, 35(2), 1-16.

Danielson, M. G., \& Karpoff, J. M. (2006). Do pills poison operating performance? Journal of Corporate Finance, 12(3), 536-559.

DeAngelo, H., \& Rice, E. M. (1983). Antitakeover Charter Amendments and Stockholder Wealth. Journal of Financial Economics, 11(1-4), 329-359.

Fahlenbrach, R. (2009). Shareholder Rights, Boards, and CEO Compensation. Review of Finance, 13(1), 81-113.

Ge, W., \& Kim, J. (2014). Boards, takeover protection, and real earnings management. Review of Quantitative Finance and Accounting, 43(4), 651-682.

Gompers, P. A., Ishii, J. L., \& Metrick, A. (2003). Corporate Governance and Equity Prices. Quarterly Journal of Economics, 118(1), 107-155.

Graham, J. R., Li, S., \& Qiu, J. (2012). Managerial Attributes and Executive Compensation. The Review of Financial Studies, 25(1), 144-186.

Heron, R. A., \& Lie, E. (2006). On the use of poison pills and defensive payouts by takeover targets. Journal of Business, 79(4), 1783-1807.

Huang, H. H., Wang, W., \& Zhou, J. (2013). Shareholder Rights, Insider Ownership and Earnings Management. Abacus, 49(1), 46-73.

Jaiswall, S. S. K., \& Bhattacharyya, A. K. (2016). Corporate governance and CEO compensation in Indian firms. Journal of Contemporary Accounting \& Economics, 12(2), 159-175.

Jensen, M. C., \& Meckling, W. H. (1976). Theory of the firm: Managerial behavior, agency costs and ownership structure. Journal of Financial Economics, 3(4), 305-360.

Jiraporn, P, Kim, Y. S., III, W. N. D. (2005). CEO Compensation, Shareholder Rights, and Corporate Governance: An Empirical Investigation. Journal of Economics and Finance, 29(2), 242-258.

Knoeber, C. R. (1986). Golden Parachutes, Shark Repellents, and Hostile Tender Offers. The American Economic Review, 76(1), 155-167.

Koenker, R., \& Basset, G. Jr. (1978). Regression Quantiles. Econometrica, 46(1), 33-50.

Lin, D., Kuo, H., \& Wang, L. (2013). Chief Executive Compensation: An Empirical Study of Fat Cat CEOS. The International Journal of Business and Finance Research, 7(2), 27-42.

Lin, D., \& Lin, L. (2014). The Interplay between Director Compensation and CEO Compensation. The International Journal of Business and Finance Research, 8(2), 11-26.

Lopes, P. F., Costa, D. F., Carvalho, F. M., \& Castro, L. G. Jr. (2016). Desempenho econômico e financeiro das empresas brasileiras de capital aberto: Um estudo das crises de 2008 e 2012. Revista Universo Contábil, $12(1), 105-121$.

Maestri, H. C. (2011). Estudo Comparado sobre a Aplicabilidade das Poison Pills no Direito Brasileiro e Norte-Americano. Revista Direito em (Dis)Curso, 4(1), 64-73.

Malatesta, P. H., \& Walkling, R. A. (1988). Poison pills securities: Stockholder wealth, profitability, and ownership structure. Journal of Financial Economics, 20, 347-376. 
Mallette, P., \& Fowler, K. L. (1992). Effects of Board Composition and Stock Ownership on the Adoption of "Poison Pills". The Academy of Management Journal, 35(5), 1010-1035.

Maltocsy, Z., Shan, Y., \& Seethamraju, V. (2012). The timing of changes in CEO compensation from cash bonus to equity-based compensation: Determinants and performance consequences. Journal of Contemporary Accounting \& Economics, 8(2), 78-91.

Martins, C. L. (2015). As poison pills e a proteção conferida aos acionistas minoritários no Brasil. (Master's thesis). Insper Instituto de Ensino e Pesquisa, São Paulo, SP, Brasil.

Nguyen, D. G. (2017). The endogeneity of poison pill adoption and unsolicited takeovers. International Journal of Managerial Finance, 14(1), 23-36.

Nguyen, P., Rahman, N., \& Zhao, R. (2018). CEO characteristics and firm valuation: a quantile regression analysis. Journal of Management \& Governance, 22(1), 133-151.

Ortiz-Molina, H. (2007). Executive compensation and capital structure: The effects of convertible debt and straight debt on CEO pay. Journal of Accounting and Economics, 43(1), 69-93.

Ozkan, N. (2011). CEO Compensation and Firm Performance: an Empirical Investigation of UK Panel Data. European Financial Management, 17(2), 260-285.

Pelucio-Grecco, M. C., Geron, C. M. S., \& Grecco, G. B. The effect of IFRS on earnings management in Brazilian non-financial public companies. Emerging Markets Review, 21, 42-66.

Portulhak, H., Theiss, V., Kühl, M. R., \& Colauto, R. D. (2017). Poison Pills e Gerenciamento de Resultados: Estudo em Companhias do Novo Mercado da BM\&FBovespa. Revista Universo Contábil, 13(2), 25-42.

Ross, S. A. (1973). The Economic Theory of Agency: The Principal's Problem. The American Economic Review, 63(2), 134-139.

Ryngaert, M. (1988). The Effect of Poison Pill Securities on Shareholder Wealth. Journal of Financial Economics, 20(1-2), 377-417.

Schepker, D. J., \& Oh, W. (2013). Complementary or Substitutive Effects? Corporate Governance Mechanisms and Poison Pill Repeal. Journal of Management, 39(7), 1729-1759.

Schepker, D. J., Oh, W., \& Patel, P. C. (2016). Interpreting Equivocal Signals: Market Reaction to Specific-Purpose Poison Pill Adoption. Journal of Management, 44(5), 1953-1979.

Sikes, S. A., Tian, X., \& Wilson, R. (2014). Investors $₫$ reaction to the use of poison pills as a tax loss preservation tool. Journal of Accounting and Economics, 57(2-3), 132-148.

Shehzad, C. T., Haan, J., \& Scholtens, B. (2010). The impact of bank ownership concentration on impaired loans and capital adequacy. Journal of Banking and Finance, 34(2), 399-408.

Sridhar, I., \& Kumar, K. K. (2015). A Panel Data Analysis of Determinants of Executive Compensation: Evidence from India. International Research Journal of Finance and Economics, 139, 112-125.

Souther, M. E. (2016). The effects of takeover defenses: Evidence from closed-end funds. Journal of Financial Economics, 119(2), 420-440. 
Appendix A. Variable definitions

\begin{tabular}{|c|c|}
\hline TotalCompensation & $\begin{array}{l}\text { Total executive compensation, measured as the sum of the logarithms of fixed compensation, } \\
\text { variable compensation and stock options exercised }\end{array}$ \\
\hline FixedCompensation & $\begin{array}{l}\text { Fixed executive compensation, measured as the sum of the logarithms of salary, fixed benefits, } \\
\text { fixed participation and other fixed compensations }\end{array}$ \\
\hline $\begin{array}{l}\text { VariableCompen- } \\
\text { sation }\end{array}$ & $\begin{array}{l}\text { Variable executive compensation, measured as the sum of the logarithms of bonus, results partici- } \\
\text { pation, meetings participation, commissions participation and other variable compensations }\end{array}$ \\
\hline PoisonPill & An indicator variable that equals one if the firm has a poison pill, and zero otherwise. \\
\hline EternityClause & $\begin{array}{c}\text { An indicator variable that equals one if the firm has an "eternity" clause poison pill, and zero } \\
\text { otherwise. }\end{array}$ \\
\hline MajorityOwnership & $\begin{array}{c}\text { An indicator variable that equals one if the firm has their largest shareholder with more than } 50 \% \\
\text { of voting shares, and zero otherwise. }\end{array}$ \\
\hline BoardSize & Total board members \\
\hline Profitability & Ratio of net income to total assets \\
\hline Size & Logarithm of net sales revenue \\
\hline Leverage & Ratio of total debt to total assets. \\
\hline Market-to-book & $\begin{array}{l}\text { Ratio of market value to total assets. Market value is calculated as the sum of market value of com- } \\
\text { mon stock, market value of preferred equity, market value of debt, and minority interest, minus } \\
\text { cash and cash equivalents }\end{array}$ \\
\hline
\end{tabular}

Appendix B. Wald test results

Panel A: Wald test results for equation (1).

\begin{tabular}{|c|c|c|c|}
\hline Variable & TotalCompensation & FixedCompensation & VariableCompensation \\
\hline PoisonPill & $5.64^{* * *}$ & $16.50^{* * *}$ & $14.05^{* * *}$ \\
\hline MajorityOwnership & 1.88 & 1.57 & $17.00^{* * *}$ \\
\hline BoardSize & $13.65^{* * *}$ & $13.87^{* * *}$ & 0.90 \\
\hline Profitability & 1.01 & 1.98 & $14.37^{* * *}$ \\
\hline Size & $19.53^{* * *}$ & $16.51^{* * *}$ & 0.79 \\
\hline Leverage & 0.84 & $2.23^{*}$ & 0.92 \\
\hline Market-to-book & 0.41 & 0.37 & \\
\hline
\end{tabular}

Panel B: Wald test estimations for equation (2).

\begin{tabular}{|c|c|c|c|}
\hline Variable & TotalCompensation & FixedCompensation & VariableCompensation \\
\hline EternityClause & $2.95^{* *}$ & $16.94^{* * *}$ & $62.90^{* * *}$ \\
\hline MajorityOwnership & $4.29^{* * *}$ & 1.22 & $11.29^{* * * *}$ \\
\hline BoardSize & $15.40^{* * *}$ & $18.38^{* * *}$ & 0.50 \\
\hline Profitability & 0.76 & 0.35 & $36.05^{* * *}$ \\
\hline Size & $28.45^{* * *}$ & $52.54^{* * *}$ & 0.48 \\
\hline Leverage & 1.63 & 1.44 & 1.20 \\
\hline Market-to-book & 0.16 & 0.33 & \\
\hline
\end{tabular}

$*, * * *, * * *$ indicate significance at the $10 \%, 5 \%$, and $1 \%$ levels (two-tailed), respectively.

\section{Como referenciar}

Azevedo, Y. G. P.; Nakao, S. H. (2019). The Influence of Poison Pills on Executive Compensation. Advances in Scientific and Applied Accounting, 12(3), Set. / Dez. p. 039-061 